\title{
Motyw Kobiety-Góry we współczesnych islandzkich filmach i serialach
}

\section{W cieniu wulkanów}

O Islandii napisano już chyba wszystko ${ }^{1}$. Państwo wielkości mojego rodzinnego Białegostoku potrafito nie jeden raz zachwycić resztę świata swoją literaturą, muzyką, filmami rodzimych twórców, ale też filmowymi plenerami, z których korzystali najwięksi producenci hollywoodzcy². Jednak o Islandii było też głośno z innych przyczyn. Przede wszystkim za sprawą kryzysu z 2008 roku (zob. Sutkowski, 2010), który zmienił podejście do życia wielu mieszkańców Ultima Thule, czy też dwa lata później, z powodu wybuchu wulkanu Eyjafjallajökull, który jeszcze przed pandemią koronawirusa sparaliżował ruch lotniczy na całym świecie. Nawiązując do tej ostatniej sytuacji, to właśnie islandzkie wulkany chciałbym uczynić punktem wyjścia dla poniższych rozważań.

Islandia to kraj kontrastów. Miejsce, które łączy ze sobą ogień i lód, nowoczesność i tradycję, wiarę w banki (pożyczki, kredyty) i w... elfy (Booth, 2015: 137). Tak wiele sprzeczności może tłumaczyć fakt, że wyspa ta leży na styku dwóch płyt tektonicznych: północnoamerykańskiej i euroazjatyckiej. To właśnie z miejsca, gdzie stykają się dwie płyty, wydobywa się lawa, która znajduje ujście w mniej więcej stu trzydziestu wulkanach obecnych na tej wyspie. Po wybuchu jednego z nich w 2010 roku bardzo popularna stała się turystyka wulkaniczna. Pojawiło się wielu turystów, wspinaczy, ludzi na skuterach śnieżnych, którzy chcieli zobaczyć z bliska „górę zionącą ogniem”. Trzeba też pamiętać, że to właśnie wulkany określają naturę tamtejszej ziemi, tworząc niekończące się pola wyschniętej lawy pokrytej mchem lub lodem, rozległe równiny czarnego piasku czy poszarpane szczyty i ogromne kratery (Gunnarsdóttir, b.r.).

1 Przykładami literatury na temat Islandii mogą być choćby takie pozycje, jak: Gabryś, 2010; Morawiec, Neubauer, 2010; 2015; Booth, 2015; Sigmundsdóttir, 2015; Klimko-Dobrzaniecki, 2016; Konefał, 2016.

2 Pejzaż Islandii był wykorzystywany między innymi w takich produkcjach jak: Śmierćnadejdziejutro (2002, reż. L. Tamahori), Sekretne życie Waltera Mitty (2013, reż. B. Stiller), Prometeusz (2012, reż. R. Scott), Interstellar (2014, reż. Ch. Nolan), Gra o tron (2011-2019). 
Kilka islandzkich wulkanów jest szerzej znanych na całym świecie i zagościło na dobre w uniwersum popkultury. Przykładem może być Snæfellsjökull, który w swojej powieści Podróż do wnętrza ziemi umieścił Juliusz Verne (2000). Kolejnym wulkanem jest Hekla - najsłynniejszy i najbardziej aktywny wulkan Islandii, znany również w średniowieczu pod nazwą „wrota do piekiet”. Poświęcam tyle uwagi tym islandzkim „płonącym górom”, by pokazać, jak ważną rolę odgrywają w tamtejszym pejzażu, tradycji czy kulturze. Co więcej, te górzyste formy plujące lawą znajdują się u samego rdzenia islandzkości, związane są bowiem z powstaniem mitu Kobiety-Góry.

\section{Kobieta-Góra}

Inga Dóra Björnsdóttir (1996) przytacza jeden z nacjonalistycznych dyskursów, według którego to właśnie natura w największej mierze przyczyniła się do powstania poszczególnych narodów, tworząc niejako unikalne obrysy ziemi i kształtując krajobraz za pomocą gór i rzek. O ile jednak w przypadku wielu europejskich państw znalezienie takich naturalnych granic mogłoby się okazać trudne, o tyle w Islandii problem ten znika, geograficzne granice pokrywają się bowiem z politycznymi. Zwolennicy takiego sposobu myślenia idą w swoich dywagacjach jeszcze dalej i zauważają, że to również natura ukształtowała ducha narodowego (język, kulturę, muzykę). Przy tym założeniu nie byłoby zatem takiego tworu jak uniwersalny człowiek, a wszystko miałoby charakter narodowy, a najczęściej miałoby swoje źródła w naturze (Björnsdóttir, 1996).

W islandzkim nacjonalistycznym dyskursie wierzono również, że siły, które stworzyły Islandczyków, były kontrolowane przez „matkę”, która odegrała w tym procesie kluczową rolę. Ta centralna figura matki (kobiecości) była używana przez długi czas do tego, by podkreślić niezależność i państwowość oraz pokazać, że Islandczycy są ukształtowani przez inną matkę niż Duńczycy, którzy kontrolowali Islandię od 1380 roku. Postać Kobiety-Góry zrodziła się więc jako swego rodzaju opozycja w stosunku do duńskiego króla jako mężczyzny/ojca. Miała ona dwa oddzielne, ale powiązane ze sobą wymiary: kulturowy/matczyny i polityczny/męski. Pierwszy obejmował islandzki język, kulturę, historię, które, jak wierzono, miały korzenie w ciele matki i były przez nią kontrolowane. Drugi wymiar natomiast obejmował islandzką polityczną moc i suwerenność. Islandczycy często stosowali tego typu strategię, na przykład podkreślając ponadczasowość ducha wyspy przez odniesienia do kanonicznych tekstów kultury, takich jak Edda (Snorri, 2013) czy Księga 
Islandczyków (Thorgilsson, 2013). Dawniej służyło to umocnieniu tożsamości narodu, pozostającego najpierw pod norweską, a później duńską kontrolą. W podobnym tonie pisze również Jakub Konefał, zauważając, że dla Islandczyków „Kobieta-Góra jest alegoryczną personifikacją ojczyzny" (Konefał, 2016: 68).

Z czasem mityczna postać Kobiety-Góry przybrała wymiar cielesny. Otóż w 1864 roku profesor Erikkur Magnusson użył jednej ze swych wizji, by stworzyć jej postać (zwaną Fjallkonan) i to właśnie ten wizerunek bardzo często był później używany w sztuce i poezji islandzkiej. Wraz z upływem czasu był on wykorzystywany przez różne grupy i na różne sposoby. Na przykład po II wojnie światowej, gdy na Islandii pojawiła się baza amerykańskich żołnierzy i około trzystu Islandek wyszło za mąż za Amerykanów i opuściło wyspę (Konefał, 2016: 138), użyto wizerunku Kobiety-Góry w agitacji, by połączyć w nim islandzką naturę i kulturę - obie symbolizujące tradycję i lojalność wobec kraju. Z czasem symbol zostat również przejęty przez feministki, które reinterpretowały go, by zdobyć polityczne poparcie w konserwatywnych kręgach i miejsca w Althigu (Konefał, 2012: 82).

\section{Kobieta-Góra i film}

Wzajemne powiązania między narodem a przyrodą, które w przypadku Islandii ucieleśniają się w postaci Kobiety-Góry, są obecne w wielu obszarach studiów filmowych. Traktują one krajobraz jako ważny element ikonograficzny i afektywny w konsolidacji narodowości (Kääpä, 2014: 27). Jak potwierdza wiele z tych badań, narracyjny i wizualny potencjał przyrody stanowi łatwy skrót dla utrwalenia poczucia autentyczności i przynależności, co jest warunkiem wstępnym wspólnoty narodowej. Na Islandii polega to na połączeniu natury z wyobraźnią narodową, z klasykami kultury narodowej, takimi jak wiersze Jonasa Hallgrimssona i obrazy Johannesa Kjarvala (Kääpä, 2014: 28). Przy tym, co godne zauważenia w kontekście analizowanej tu problematyki, islandzka natura jest często kodowana jako wyraźnie kobieca, szczególnie w kontekście czystości ziemi narodowej i potrzeby zachowania jej niezależności i suwerenności (Kääpä, 2014: 36). Taka perspektywa z kolei pokrywa się z tym, jak rozumiany jest symbol Kobiety-Góry. Idealna kobieta często ukazywana jest w islandzkich tekstach kultury jako osoba nieskażona złem cywilizacji i żyjąca w zgodzie z naturą. Modelowa Islandka ma być silnie związana z porządkiem nadnaturalnym, a jej charakter powinien łączyć takie cechy jak delikatność i hart ducha (Konefał, 2016: 144). Co ciekawe, podobny motyw wykorzystuje w swojej twórczości najsłynniejsza ambasadorka Islandii - Björk. Gdy przyjrzymy się jej sesjom fotograficznym albo okładkom jej płyt czy teledyskom, 
dostrzeżemy w wykreowanej przez nią postaci silny związek z naturą czy siłami ponadnaturalnymi.

To zainteresowanie przyrodą i silnymi postaciami kobiecymi widać już w początkach islandzkiej kultury, jak zauważają bowiem Jakub Morawiec i Łukasz Neubauer:

Mimo znacznego stopnia maskulinizacji świata sag nie da się pominąć roli kobiet w poszczególnych narracjach. Ich obecność, choć często drugoplanowa, w istocie jest dla danej historii wręcz kluczowa. Jako żony, matki oraz wdowy kobiety pełnity ważne funkcje w społeczności islandzkiej i status ten jest widoczny także w sagach. [...] Silne i charyzmatyczne kobiety nie tylko strzegą honoru swoich mężów i krewnych. Przypominają im także o definiującym ich losy przeznaczeniu (Morawiec, Neubauer, 2015: 26).

Za przykład może posłużyć Saga o Gislim lub Saga rodu z Laxdalu, jedyna saga, której główną bohaterką jest kobieta - Guðrún Ósvífrsdóttir.

Takie postacie zasiedlały nie tylko sagi, ale też zapełniały karty powieści, czego przykładem może być choćby dzieło Hakkdora Kiljana Laxnessa Salka Valka (1963), w którym mamy do czynienia z silną, niezależną kobietą, nieodłącznie związaną z naturą. Tak wykreowane postacie kobiet stały się kamieniem węgielnym również dla islandzkiego kina i pojawiały się choćby w takich filmach jak: Soley (1982, reż. M. Pavolettoni, R. Óskarsdóttir), Śmiech mewy (2001, reż. A. Guðmundsson) czy Sokoty (2002, reż. T.F. Fridriksson) (Norðfjörð, 2010: 27).

\section{Kobieta-Góra i Islandia}

Z powyższych rozważań wynika, że postać Kobiety-Góry jest mocno zakorzeniona w islandzkiej kulturze. Co ciekawe, motyw ten we współczesnej kinematografii jest wykorzystywany na różne sposoby. Jednym z nich jest utożsamianie tej mitycznej postaci z samą Islandią, co możemy obserwować choćby w coraz bardziej popularnych serialach kryminalnych kręconych na tej wyspie.

Produkcje tego typu określa się mianem Nordic Noir. Szczególnie wyspecjalizowali się w nich Szwedzi i Duńczycy, ale do estetyki tej nawiązuje również ostatni głośny serial fiński zatytułowany Karppi (2018-). Z czasem twórcy seriali skandynawskich stopniowo przekształcali estetykę Nordic Noir i zaczęli poszukiwać nowych rozwiązań. Norwegowie na przykład często nawiązują do swojej mitologicznej przeszłości, jak choćby w serialu Ragnarok (2020-) czy produkcji Beforeigners (2019-). Islandczycy natomiast podkreślają w swoich serialach właśnie rolę natury, która jest 
nie tylko tłem, ale i równoprawnym uczestnikiem fabuły, wpływającym na jej kształt w takim samym stopniu jak bohaterowie. Taki zabieg widać bardzo wyraźnie choćby w miniserialu The Cliff (Hamarinn) (2009) czy też w serialu Trapped (2015-). W tym przypadku właśnie warunki klimatyczne wyznaczyły bieg akcji i decydowały o poczynaniach głównych bohaterów.

Akcja serialu The Cliff ma miejsce na prowincji. Obserwujemy ciąg wypadków związanych z pracami budowlanymi, które prowadzone są w rzekomym „elfim miejscu”, zwanym Hammarin. Jest to o tyle ważne, że według lokalnej mitologii w Hafnarfjörður, gdzie ma miejsce akcja serialu, klif jest królewskim „domem elfów" (Hansen, Waade, 2017: 236). W tym przypadku, podobnie jak w szwedzkiej produkcji Jordskott (2015-2017), przyrodę traktuje się jako coś absolutnego, w co nie można ingerować, utożsamiana jest ona bowiem z matką Islandią, a ta jest doskonała w swoim odwiecznym trwaniu. Każdy zatem zamach na taki stan rzeczy musi spotkać się z karą.

Jak się okazuje, na Islandii odnotowano o wiele więcej przykładów, w których rzekomo elfy dochodzity swoich spraw. Pisze o tym Michael Booth w książce Skandynawski raj. O ludziach prawie idealnych (Booth, 2015). Podsumowując tego typu „wypadki”, autor zauważa, że w ten sposób „nadprzyrodzeni stają w obronie wartości związanych z życiem w zgodzie z naturą" (Booth, 2015: 137). Podobne motywy fabularne możemy zauważyć właśnie w serialu Trapped, w którym Chińczycy chcą budować na Islandii rurociąg, ingerując jednocześnie w krajobraz Ultima Thule, co powoduje odwet islandzkiej natury w postaci zawiei, zamieci i śnieżyc, które paraliżują życie w miasteczku, jednocześnie odcinając je od reszty wyspy. Jest to motyw fabularny, który pojawiał się w wielu wcześniejszych islandzkich produkcjach:

Motyw gwałtu na nieskażonej naturze ojczyzny, często personifikowanej przez postać niewinnej dziewicy, to popularny element narracji, wielokrotnie wykorzystywany także w islandzkim dyskursie narodowym. Motyw ten wiąże się też z symboliczną postacią Kobiety-Góry [...] (Konefał, 2016: 46).

W przypadku omawianego serialu warto zwrócić uwagę już na samą jego czotówkę, w której obserwujemy zestawione ze sobą zimowe islandzkie krajobrazy i fragmenty martwego, ludzkiego ciała. W ten sposób sekwencja ta sugeruje metaforycznie i formalistycznie związek natury i człowieka. Ponadto przesunięte są tutaj również znaczenia. Ciało jest bowiem rozumiane topograficznie, a krajobraz kryminalistycznie (Hansen, Waade, 2017: 241). Obrazy te nasuwają również widzom skojarzenie, że ten zimowy górski krajobraz może być równie niebezpieczny jak sam 
morderca. Jednocześnie mamy do czynienia z romantyczną wizją przyrody poprzez ukazanie jej potęgi i siły, która to strategia umniejsza jednocześnie sprawy ludzkie i pokazuje, że to natura decyduje o losie człowieka, a nie on sam. Natura często jest ukazywana przy tym właśnie pod postacią zaśnieżonych szczytów, które otaczają miasteczko lub z których schodzą śnieżne lawiny.

Śledząc fabułę serialu, obserwujemy również niechęć Islandczyków do duńskich sąsiadów, czego przykładem jest napięta sytuacja między lokalną policją a kapitanem duńskiego promu³. Cała sekwencja jest również dobrym przykładem tego, że w pojęciu Islandczyków największym zagrożeniem dla ich ojczyzny są przybysze z zewnątrz (Duńczycy, Litwini). Podobny motyw bardzo często pojawiat się w kontekście Kobiety-Góry i zagrożenia, jakie może spotkać islandzkie kobiety ze strony przybyszów z innych krajów - tak jak miało to miejsce w latach pięćdziesiątych ubiegłego wieku, kiedy - jak już wspomniałem - na Islandię przybyli amerykańscy żołnierze (w liczbie 40 000, co równało się liczbie mężczyzn w wieku produkcyjnym na wyspie), z których część wybierała za żony Islandki, a następnie wyjeżdżała z nimi do Stanów Zjednoczonych. Motyw uwiedzenia mieszkanek Ultima Thule i doprowadzenia ich do tragedii przez mężczyznę z zagranicy pojawiał się między innymi w filmach Agnes (1995, reż. E. Edwardson) czy Honor Domu (1999, reż. G. Halldórsdóttir) (Konefał, 2016).

Inny sposób użycia symbolu Kobiety-Góry jako Islandii pojawia się między innymi w takich filmach jak 101 Reykjavik (2000, reż. B. Kormákur) czy Barany. Islandzka opowieść (2015, reż. G. Hákonarson). W obu tych produkcjach jeden z bohaterów, w wyniku niekorzystnych dla niego zdarzeń, znajduje się w bardzo trudnej dla siebie sytuacji i szuka schronienia w objęciach Kobiety-Góry, czyli islandzkiej ziemi. Hlynur, główna postać najsłynniejszego swego czasu islandzkiego filmu 101 Reykjavik, rozczarowany swoim życiem, zmęczony narkotykami, alkoholem i pornografią, mieszkaniem z matką i skomplikowaną relacją erotyczną z jej partnerką, postanawia popełnić samobójstwo. Udaje się więc na jedno z otaczających Reykjavik wzgórz, kładzie się na ziemi i postanawia umrzeć zasypany gęstym białym śniegiem. Hlynur to typowy antywiking, wieczny mały chłopiec, który nie potrafi odciąć się od matki i wziąć odpowiedzialności za własne rozchwiane życie, dlatego odpowiedzi szuka w czymś, co jest odwieczne, stałe, związane z naturalnym porządkiem. W tym celu udaje się na pobliskie wzgórze, by zasnąć $w$ ramionach Kobiety-Góry, ponieważ tylko ona bezwarunkowo zaakceptuje swego syna takim, jaki jest.

3 Napięta sytuacja między lokalną policją a kapitanem duńskiego promu wiele mówi o burzliwej historii łączącej oba kraje (Islandia wyswobodziła się spod duńskiego panowania dopiero w 1944 roku). Ponadto nie bez znaczenia jest fakt, że kapitana statku gra duński aktor - Bjarne Henriksen, znany z serialu Forbrydelsen (2007-). Naciska on na Andriego - głównego bohatera, by ten mówił po duńsku. 
Innym przykładem podobnego wykorzystania omawianego tu motywu może być film Barany. Islandzka opowieść. Jest to historia dwóch skłóconych braci, którzy muszą zakończyć czterdziestoletni spór, aby chronić swój dotychczasowy styl życia i to, co najbardziej kochają. Gdy owce jednego z nich znajdują się w zagrożeniu, bracia postanawiają zakopać topór wojenny i zimą wraz ze zwierzętami udają się w góry. Tam jednak spotyka ich śnieżyca, która uniemożliwia dalsze działania. W związku z tym jeden z nich wykopuje w śniegu jamę, by tam skryć się z tracącym przytomność bratem. W ostatniej scenie widzimy jak dwóch półnagich starszych mężczyzn, ukrytych głęboko w islandzkiej ziemi, ogrzewa swoje ciała we wzajemnym braterskim uścisku. Jedynym ratunkiem przed cywilizacją i bezdusznym prawem ustanowionym przez człowieka jest właśnie próba ponownego złączenia się z naturą, z Kobietą-Górą.

Kiedy przyglądamy się fabułom tych filmów, idealnie zdaje się pasować do nich jedna z charakterystyk twórczości najsłynniejszego Islandczyka - Laxnessa. Dostrzegamy w nich bowiem, tak jak u noblisty:

Atmosferę walki o życie [...]. Bohaterów, którzy są naiwni, na swój sposób prymitywni i obcesowi. Widzimy jałowość i dzikość natury, niespokojne morze i bardzo ścisły związek między psychiką bohaterów a otaczającą ich dziką naturą (Norðfjörð, 2010: 27).

\section{Kobieta-Góra i... kobieta}

Na Islandii kobiety mają dużo władzy politycznej, przynajmniej w porównaniu z resztą Europy. W 2009 roku w rządzie tego kraju zasiadało tyle samo kobiet co mężczyzn. Islandia jako pierwsza również może poszczycić się wyborem, w demokratycznym głosowaniu, kobiety na stanowisko głowy państwa (funkcję tę od roku 1980 trzykrotnie pełniła Vigdís Finnbogadóttir). Wspomniana już przeze mnie Björnsdóttir w swoim artykule zestawia właśnie postać pierwszej kobiecej prezydent Islandii z postacią Kobiety-Góry. Pokazuje też jak Finnbogadóttir korzystała w trakcie sprawowania swojej funkcji z symboliki przynależnej mitologicznej postaci Matki Islandii.

Wspominałem już, że Kobieta-Góra jest również często pewnym rodzajem pierwowzoru, jeśli chodzi o figury silnych kobiet w islandzkiej literaturze czy filmie, symbolizując naturę lub Islandię, ale przede wszystkim wielką siłę kobiecości, związaną z naturą i elementami ponadnaturalnymi. 
Jednym z przykładów może być najnowszy islandzki serial wyprodukowany przez Netflix, czyli Valhalla Murders (2019). I choć zgadzam się z opiniami, że serial ten powiela wiele schematów Nordic Noir i jest przewidywalny, jeśli chodzi o fabułę czy rozwiązania formalne, to jednak warto przyjrzeć mu się właśnie pod kątem głównej bohaterki - twardej, doświadczonej policjantki Katy. Musi ona zmagać się nie tylko ze skomplikowanym śledztwem, ale też z osobistymi problemami związanymi z dorastającym synem, nadopiekuńczą i schorowaną matką czy byłym mężem. W jednej z pierwszych scen poznajemy ją, gdy trenuje pływanie na basenie. Ta scena „ustawia” nam już niejako główną bohaterkę, dowiadujemy się bowiem, że jest silna, wysportowana i związana z islandzką naturą właśnie poprzez wodę, w której z taką lekkością się porusza. Zresztą w ostatniej scenie Kata uratuje swego policyjnego partnera, nurkując w lodowatej islandzkiej zatoce.

Myślę też, że postać Katy możemy odnieść do mitycznych skandynawskich wojowniczek. Już sam tytuł serialu odsyła nas bowiem do skandynawskiej mitologii ${ }^{4}$. Słowo „Valhalla” oznacza krainę wiecznej szczęśliwości, miejsce spoczynku wojowników, do którego po walce posyłat ich Odyn. Do Valhalli sprowadzały ich natomiast walkirie, które były kimś w rodzaju „wyborów zabitych”. Uważano je za kobiece duchy rzezi, co łączy się przecież z seryjnymi morderstwami, z którymi mamy do czynienia w przypadku serialu kryminalnego. To właśnie Kata w największej mierze przyczynia się do rozwiązania zagadki Valhalli i pozwala duszom wykorzystywanych chłopców wreszcie spocząć w spokoju. Warto też zwrócić uwagę, że Kata nie jest jedyną silną, kobiecą bohaterką w tym serialu. W rozwiązaniu śledztwa bardzo pomaga również odważna i bezkompromisowa dziennikarka Selma, która przekonuje dorosłych już wychowanków ośrodka do przejmujących zwierzeń. Równie zdecydowaną i silną osobowością jest Helga - szefowa Katy.

W kontekście tych rozważań zwrócitbym jeszcze uwagę na film Kobieta idzie na wojnę (2018, reż. B. Erlingsson). Główną bohaterką jest pięćdziesięcioletnia Halla, która prowadzi podwójne życie. Z jednej strony bowiem, niczym superbohaterka, samodzielnie prowadzi terrorystyczne działania przeciw potężnemu koncernowi, który stanowi zagrożenie dla islandzkiego środowiska i ukrywa się pod pseudonimem „Kobieta z gór” (co jest ewidentnym nawiązaniem do omawianej tu mitycznej postaci matki Islandczyków). Z drugiej zaś jest dyrygentką amatorskiego chóru i stara się o adopcję ukraińskiej dziewczynki. Co ciekawe, odnajdujemy w tej postaci wszystkie cechy przypisywane Kobiecie-Górze. Otóż Halla jest bardzo

4 Tropów, które odsyłałyby do skandynawskiej mitologii, znajdziemy tam znacznie więcej. Otóż na początku filmu zamordowany zostaje mężczyzna o imieniu Thor, a w mitologii skandynawskiej Thor był synem Odyna, którego z kolei w tym serialu może reprezentować Petur, będący w pewnym momencie kierownikiem Valhalli - ośrodka dla nastoletnich chłopców. Sam fakt, że Thor ginie na początku serialu, może być zapowiedzią tego, w którą stronę potoczy się akcja. Ponadto pojawia się jeszcze postać innego nastoletniego wychowanka Valhalli - Fannara, który w pewnym momencie gra w grę o nazwie Valr od Valkyrie (Datta, 2020). 
mocno związana z islandzką przyrodą, której broni, ale która też daje jej schronienie. Potrafi „wtopić się” w wulkaniczną skałę bądź schować przed nieprzyjacielem w gęstym islandzkim mchu. Główną bohaterkę możemy też utożsamiać z samą Islandią, która broni się przed zakusami biznesmenów z zewnątrz (w tym przypadku z Chin) i chce ocalić tych, którzy od wieków uprawiają islandzką ziemię. Widzimy też w tej postaci elementy ponadnaturalne, które skumulowane są w jej siostrze bliźniaczce (obie siostry gra ta sama aktorka - Halldóra Geirharðsdóttir), wielkiej znawczyni jogi i mistyki Wschodu.

\section{Podsumowanie}

Górzysto-wulkaniczny krajobraz Islandii przyczynił się do ukształtowania mitu Kobiety-Góry, który bardzo szybko został przechwycony przez tamtejszą literaturę, kulturę popularną, filmy i seriale. Kobieta-Góra stała się matką wszystkich Islandczyków, symbolizując samą Islandię, ale też siłę kobiecości, która znalazła swój wyraz w wielu wykreowanych postaciach kobiet, czerpiących swą siłę z tamtejszej surowej natury. Okazuje się zatem, że droga od wulkanu plującego lawą do bohaterek współczesnego filmu islandzkiego wcale nie jest tak daleka i skomplikowana, jak mogłoby się wydawać na pierwszy rzut oka. A tym, co łączy naturę i kulturę, jest właśnie Kobieta-Góra.

\section{Bibliografia}

Björnsdóttir I.D. (1996), The Mountain Woman and the Presidency, [w:] G. Pallson, E.P. Durrenberger (red.), Images of Contemporary Iceland: Everyday Lives and Global Contexts, lowa: University of lowa Press, s. 106-125.

Booth M. (2015), Skandynawski raj. O ludziach prawie idealnych, Kraków: Wydawnictwo Uniwersytetu Jagiellońskiego.

Datta T. (2020), 'The Valhalla Murders' Ending, Explained, https://www.thecinemaholic.com/the-valhalla-murders-ending-explained/ (dostęp: 30.07.2020).

Gabryś M. (2010), Islandzkie zabawki. Zapiski z wyspy wulkanów, Bielsko-Biała: Wydawnictwo Pascal.

Gunnarsdóttir N., Wulkany na Islandii. Wszystko, co musisz o nich wiedzieć, https://guidetoiceland.is/pl/islandzka-natura/wulkany-na-islandii (dostęp: 29.07.2020).

Hansen T.K., Waade A.M. (2017), Trapped and Original Noir from Iceland and Norway, [w:] T.K. Hansen, A.M. Waade, Locating Nordic Noir. From Beck to The Bridge, Copenhagen: Palgrave Macmillan, s. 236-241.

Kääpä P. (2014), Ecology and Contemporary Nordic Cinemas. From Nation-building to Ecocosmopolitanism, London-Oxford-New York -New Delhi-Sydney: Bloomsbury.

Klimko-Dobrzaniecki H. (2016), Zostawić Islandię, Warszawa: Oficyna literacka Noir sur Blanc.

Konefał S. (2012), Female Protagonists in Contemporary Islandic Cinema , ,Studia Humanistyczne AGH", t. 11(2), s. 133-146.

Konefał S. (2016), Kino Islandii. Tradycja i ponowoczesność, Gdańsk: Wydawnictwo w podwórku.

Laxness H.K. (1963), Salka Valka, Warszawa: Państwowy Instytut Wydawniczy.

Morawiec J., Neubauer Ł. (2015), Sagi islandzkie. Zarys dziejów literatury staronordyckiej, Warszawa: Wydawnictwo Naukowe PWN.

Morawiec J., Neubauer Ł. (red.) (2010), Islandia. Przewodnik nieturystyczny, Warszawa: Wydawnictwo Krytyki Politycznej. 
Norðfjörð B.A. (2010), Adapting a Literary Nation to Film: National Identity, Neoromanticism and the Anxiety of Influence, "Scandinavian-Canadian Studies/Études Scandinaves au Canada", vol. 19, s. 12-40.

Sigmundsdóttir A. (2015), Mała księga Islandczyków, Katowice: Innymi Słowy.

Snorri S. (2013), Edda starsza i młodsza, Sandomierz: Wydawnictwo Armoryka.

Sutkowski M. (2010), Ostateczny krach systemu korporacji, [w:] J. Morawiec, Ł. Neubauer (red.), Islandia. Przewodnik nieturystyczny, Warszawa: Wydawnictwo Krytyki Politycznej, s. 132-145.

Thorgilsson A. (2013), Księga Islandczyków, Sandomierz: Wydawnictwo Armoryka.

Verne J. (2000), Podróż do wnętrza Ziemi, Kraków:Wydawnictwo Zielona Sowa.

\section{Filmografia}

101 Reykjavik (2000), reż. B. Kormákur.

Agnes (1995), reż. E. Edwardson.

Barany. Islandzka opowieść (2015), reż. G. Hákonarson.

Beforeigners (2019-).

Forbrydelsen (2007-).

Gra o tron (2011-2019).

Honor Domu (1999), reż. G. Halldórsdóttir.

Interstellar (2014), reż. Ch. Nolan.

Jordskott (2015-2017).

Karppi (2018-).

Kobieta idzie na wojnę (2018), reż. B. Erlingsson.

Prometeusz (2012), reż. R. Scott.

Ragnarok (2020-).

Sekretne życie Waltera Mitty (2013), reż. B. Stiller.

Sokoły (2002), reż. T.F. Fridriksson.

Soley (1982), reż. M. Pavolettoni, R. Óskarsdóttir.

Śmiech mewy (2001), reż. A. Guð̀mundsson.

Śmierć nadejdzie jutro (2002), reż. Lee Tamahori.

The Cliff (Hamarinn) (2009).

Trapped (2015-).

Valhalla Murders (2019). 